\title{
Early Modern Jesuit Science. A Historiographical Essay
}

\author{
Sheila J. Rabin \\ Saint Peter's University, 2641 John F. Kennedy Boulevard, Jersey City, NJ 07306 \\ srabin@saintpeters.edu
}

\begin{abstract}
The traditional narrative of early modern science, or the scientific revolution, made the Catholic church appear anti-scientific. However, as scholars during the last three decades have reconstructed science in the sixteenth and seventeenth centuries, they have found that members of the Catholic church and the Jesuits in particular, despite their rejection of Copernican astronomy, contributed significantly to the advancement of science in those centuries. Many members of the Society of Jesus were both practitioners of mathematics and science and teachers of these subjects. They were trained in mathematics and open to the use of new instruments. As a result they made improvements in mathematics, astronomy, and physics. They kept work alive on magnetism and electricity; they corrected the calendar; they improved maps both of the earth and the sky. As teachers they influenced others, and their method of argumentation encouraged rigorous logic and the use of experiment in the pursuit of science. They also used mathematics and science in their missions in Asia and the Americas, which aided their successes in these missions. Historians of science now realize that detailing the progress of science in the sixteenth and seventeenth centuries requires the inclusion of Jesuit science.
\end{abstract}

\section{Keywords}

Christoph Clavius - Giambattista Riccioli - Nicolaus Copernicus - Galileo Galilei Athanasius Kircher - China - Matteo Ricci - Americas - mathematics - astronomy physics - cartography - telescope - natural history

* The author is grateful to Saint Peter's University for a Faculty Research award for 2012-2013 that gave her time to research this article. She also thanks Jay Barksdale of the New York Public Library who heeded her pleas to extend her Wertheim Study privileges. 


\section{Introduction: The "Scientific Revolution"}

In 1931, the historian Herbert Butterfield warned against the danger of what he called "the Whig interpretation of history." He defined this as "the tendency in many historians to write on the side of Protestants and Whigs, to praise revolutions provided they have been successful, to emphasise certain principles of progress in the past and to produce a story which is the ratification if not the glorification of the present."1 In particular, he noted that this caused historians "to produce a scheme of general history which is bound to converge beautifully upon the present-all demonstrating throughout the ages the workings of an obvious principle of progress, of which the Protestants and whigs [sic] have been the perennial allies while Catholics and tories [ $s i c]$ have perpetually formed obstruction." ${ }^{2}$ How ironic that eighteen years later, this same Herbert Butterfield gave us an overview of early modern science that demonstrated the "obvious principle of progress" with the Protestants as allies and the Catholics as obstructers of that progress. According to Butterfield, this period in history, commonly called the scientific revolution, "overturned the authority in science not only of the middle ages but of the ancient world-since it ended not only in the eclipse of scholastic philosophy but in the destruction of Aristotelian physics." Consequently, "it outshines everything since the rise of Christianity." Though there were Catholics involved in this movement, "[i]n the long run it was Protestantism which for semi-technical reasons had an elasticity that enabled it to make alliance with the scientific and rationalist movements." ${ }^{4}$

The idea of a revolution that started modern science goes back to Immanuel Kant's preface to the second edition of his Critique of Pure Reason. ${ }^{5}$ This view of a revolution in science during the sixteenth and seventeenth centuries held sway in the historiography for about 200 years. ${ }^{6}$ This traditional narrative privileged the discoveries in physics and astronomy that reaffirmed the

1 Herbert Butterfield, The Whig Interpretation of History (New York: Norton, 1965), v.

2 Ibid., 11.

3 Herbert Butterfield, The Origins of Modern Science, rev. ed. (New York: Free Press, 1965), 7.

4 Ibid., 70. The belief that Protestantism was more conducive to scientific thought than Catholicism has had a long life. See, for example, Peter Harrison, The Bible, Protestantism, and the Rise of Natural Science (Cambridge: Cambridge University Press, 1998).

5 H. Floris Cohen, The Scientific Revolution: A Historiographical Inquiry (Chicago: University of Chicago Press, 1994) gave a critical outline of the historiography of the concept of a scientific revolution.

6 In addition to Butterfield, some prominent twentieth-century works include: E.A. Burtt, The Metaphysical Foundations of Modern Science (London: Kegan Paul, 1924; 2d rev. ed. rpt. Mineola: Dover, 2003); Alexandre Koyré, From the Closed World to the Infinite Universe 
heliocentric cosmos of Nicolaus Copernicus [Mikołaj Kopernik] (1473-1543) and posited a major break with the past that culminated in the physics of Isaac Newton (1642-1727). It was a story of great individuals, of heroes and villains. Any person or institution that stood by Aristotelian physics and Ptolemaic astronomy, any person or institution that rejected what was seen as the forward march of science, was the villain in the story. The Catholic church was particularly evil: it not only rejected the new science but persecuted Galileo for supporting it. The Jesuits rejected the Copernican system and continued to foster Aristotelian philosophy, and they stood by the church in the Galileo trial; therefore, the traditional narrative excluded them from any positive contributions to the new science.

The traditional narrative has been challenged during the last few decades. Scholars have questioned the idea of a revolution in science. ${ }^{7}$ Just as medievalists "revolted" against the Burckhardtian concept of the Renaissance as a break from the Middle Ages, ${ }^{8}$ historians of medieval science resented the way their subject was dismissed as unworthy of study and stressed the contributions of the Middle Ages to science and technology and the continuity between the periods. ${ }^{9}$ Scholars of early modern science also began to notice continuities with the Middle Ages and differences from modern science. ${ }^{10}$ The use of the

(Baltimore:Johns Hopkins, 1957); E.J. Dijksterhuis, The Mechanization of the World Picture: Pythagoras to Newton, trans. C. Dikshoorn (Oxford: Oxford University Press, 1961).

Katharine Park and Lorraine Daston in their introduction to volume 3 of The Cambridge History of Science (Cambridge: Cambridge University Press, 2006), which covers early modern science, draw attention to their avoidance of the term "scientific revolution" (12). Steven Shapin cleverly began his textbook, The Scientific Revolution (Chicago: Chicago University Press, 1996) with the words, "There was no such thing as the Scientific Revolution, and this is a book about it" (1).

8 Wallace K. Ferguson, The Renaissance in Historical Thought: Five Centuries of Interpretation (Boston: Houghton Mifflin, 1948; rpt. Toronto: University of Toronto Press, 2006) titled his chapter on the reaction against Burckhardt "The Revolt of the Medievalists."

9 See, for example, Lynn Thorndike, A History of Magic and Experimental Science, 8 vols. (New York: Columbia University Press, 1923-1958); Pierre Duhem, Le système du monde: histoire des doctrines cosmologiques de Platon à Copernic, 10 vols. (Paris: A. Hermann, 19131959); Lynn White, Medieval Technology and Social Change (Oxford: Oxford University Press, 1966).

10 For revised views of early modern science, in addition to the Park and Daston volume mentioned above, see, for example, David C. Lindberg and Robert S. Westman, eds., Reappraisals of the Scientific Revolution (Cambridge: Cambridge University Press, 1990); Margaret J. Osler, ed., Rethinking the Scientific Revolution (Cambridge: Cambridge University Press, 200o); Pamela H. Smith, "Science on the Move: Recent Trends in the History of Early Modern Science," Renaissance Quarterly 62 (2009): 345-375. 
word "science" is anachronistic; scholars still studied natural philosophy in the universities, and there was no professional class of scientists. In the sixteenth and seventeenth centuries, cartography and chronology were part of the study of the natural world, and subjects that are today anathema to scientists (astrology, alchemy, and magic) were an integral part of that study. Even the traditional subjects that seemed to be at the heart of the scientific revolution have been undergoing revision, as historians of science have realized that Aristotle was still useful. Not only was a sun-centered universe not obvious, but important contributions were made to astronomy without its adoption. In addition to a small number of giants in science, historians have noted that change was brought about by lesser individuals and by groups of people studying the natural world. Moreover, just as scholars in all fields of Renaissance studies have been expanding their geographical focus to the world outside Europe, so historians of science have been looking at how the interaction with the wider world affected the study of nature. Particularly over the past three decades, as historians of science shed their Whig history and engaged with the early modern period in all its complexity, they found Catholic intellectuals and members of religious orders engaged in the study of the natural world; " $t]$ here was one order, however, that stands out from all others as the scientific order without rival in seventeenth-century Catholicism, and that of course is the Society of Jesus."11

\section{The Jesuit Pursuit of Science and Mathematics}

J.L. Heilbron was one of the first scholars to draw attention to the importance of the Jesuits in the advancement of seventeenth-century science. In his book on early modern electricity, he highlighted the contribution of the Jesuits: "Knowledge about electricity was kept alive during the seventeenth century by Jesuit polymaths. They also enriched the subject with valuable observations." ${ }^{\prime 2}$ Heilbron pointed out the importance of mathematics in the Jesuit curriculum; it was viewed as a practical discipline, necessary for the study of astronomy,

11 William B. Ashworth, Jr., "Catholicism and Early Modern Science," in God and Nature: Historical Essays on the Encounter between Christianity and Science, eds. David C. Lindberg and Ronald L. Numbers, 136-66 (Berkeley: University of California Press, 1986), 154.

12 J.L. Heilbron, Electricity in the 17th and 18th Centuries: A Study of Early Modern Physics, part 1, chap. 2, sect. 1 on the Jesuits (Berkeley: University of California Press, 1979), 101. The chapter was reprinted in idem, Elements of Early Modern Physics (Berkeley: University of California Press, 1982), 93. 
geography, chronology, military technology, navigation, and surveying, subjects not just intended for the Jesuits-in-training but for sons of aristocrats in Jesuit schools preparing for a military or governmental career. Thus, Jesuits were well trained in the mathematical sciences, able both to teach and practice them. Both aspects of the Jesuit contribution to astronomy and physics came through in Heilbron's book, The Sun in the Church. ${ }^{13}$ This work showed how the need to determine the spring equinox led to important advances in observational astronomy. Heilbron studied meridian lines in churches; a hole in the wall allowed the sun to shine through and make a path along the meridian on the floor, which observers followed. One of the most important observers was Giovanni Domenico Cassini (1625-1712), who studied with the Jesuits, and Heilbron credited them for directing him into astronomy. ${ }^{14}$ Cassini's observations on meridian lines was the first observational confirmation of Kepler's elliptical orbits, and Cassini's Jesuit colleagues Giambattista Riccioli (1598-1671) and Francesco Maria Grimaldi (1618-1663) verified his observations. ${ }^{15}$ Peter Dear has shown that Jesuit work on astronomy and optics was significant in developing the concept of experiment in the seventeenth century. ${ }^{16}$ The Jesuits started with an Aristotelian basis for their natural philosophy, but the "Aristotelian model of a science adopted by the Jesuits took scientific knowledge to be fundamentally public: scientific demonstration invoked necessary connections between terms formulated in principles that commanded universal assent."17 Dear looked at the work on astronomy and optics of the Jesuits Giuseppe Biancani (1566-1624) and Christoph Scheiner (1573-1650) and concluded that they "employed techniques designed to incorporate recondite, constructed experiences into properly accredited knowledge about the natural world."18 Heilbron and Dear showed Jesuits working within the framework of the Aristotelian tradition, manipulating and massaging it to yield new ways of looking at nature.

13 J.L. Heilbron, The Sun in the Church: Cathedrals as Solar Observatories (Cambridge: Harvard University Press, 1999).

14 Ibid., 83-84.

15 Ibid., 107-112.

16 Peter Dear, Discipline and Experience: The Mathematical Way in the Scientific Revolution, chap. 2, "Experience and Jesuit Mathematical Science: The Practical Importance of Methodology" (Chicago: University of Chicago Press, 1995); see also, idem, "Jesuit Mathematical Science and the Reconstitution of Experience in the Early Seventeenth Century," Studies in History and Philosophy of Science 18 (1987): 121-164.

17 Dear, Discipline, 44.

18 Ibid., 61. 
Mordechai Feingold wrote about Jesuits as typical seventeenth-century "savants" who "were quite open and adventurous in their discussions despite the suspicions that such exchanges, especially with 'heretics,' could elicit." ${ }^{19} \mathrm{He}$ suggested that much modern science made its way into their teaching, noting "not a few Jesuits incorporated" the very controversial subject of atomism "into their lectures." 20 Feingold's fine collection of essays on various aspects of Jesuit science, Jesuit Science and the Republic of Letters, has chapters on some of the major Jesuit scholars (Ugo Baldini on Christoph Clavius, Alfredo Dinis on Giambattista Riccioli, Paula Findlen on Athanasius Kircher), scientific controversies of the times (Edward Grant on cosmology, William A. Wallace on Jesuits and Galileo, Roger Ariew on Jesuits and Descartes), patronage (Martha Baldwin on Jesuit book production), and lesser studied areas of Europe (Victor Navarro on Spain, G.H.W. Vanpaemel on the Low Countries). Augustín Udías compiled a list of the Jesuit astronomical observatories and their directors around the world both before and after the suppression, ${ }^{21}$ a breathtaking testament to the interest of members of the Society in astronomy.

Other scholars writing on Jesuit science have concentrated on geographical areas within Europe. Marcus Hellyer looked at Jesuit education and writings in the German territories. ${ }^{22}$ Like Dear, he found that Jesuit natural philosophy was transformed "from a largely scholastic body of knowledge and discourse into an experimental, mathematized science." ${ }^{23}$ He closely examined writings, particularly those of the Jesuit Kaspar Schott (1608-1666), regarding the air pump. The air pump's inventor, Otto von Guericke (1602-1686), claimed that it could create a vacuum. But according to Aristotelian physics there could be no vacuum; so Schott basically ignored the vacuum but concentrated on experimenting with atmospheric air. ${ }^{24}$ Antonella Romano and Bernard Barthet focused on the Jesuits in France. ${ }^{25}$ Romano started with the mathematics program

19 Mordechai Feingold, "Jesuits: Savants," in Jesuit Science and the Republic of Letters, Feingold, ed., 1-45 (Cambridge, MA: MIT Press, 2003), 23-24.

20 Ibid., 27.

21 Augustín Udías, Searching the Heavens and the Earth: The History of Jesuit Observatories (Dordrecht: Kluwer Academic Publishers, 2003).

22 Marcus Hellyer, Catholic Physics: Jesuit Natural Philosophy in Early Modern Germany (Notre Dame: University of Notre Dame Press, 2005). For more on Hellyer's book, see the essay by Stephen Schloesser in this issue of the JJS.

23 Ibid., 5 .

24 Ibid., chap. 7 .

25 Antonella Romano, La Contre-Réforme mathématique: Constitution et diffusion d'une culture mathématique jésuite à la Renaissance (1540-1640) (Rome: École français de Rome, 
set forth by Christoph Clavius (1538-1612) in the Collegio Romano and showed how that program was implemented in various French localities. Her appendices have much information for future scholars of the Jesuits in France before the suppression: lists of teachers of mathematics with places of employment and other biographical details. Barthet examined the use of the occult, particularly alchemy, magic, and Kabbalah, to explain certain phenomena studied by Jesuits in France during the late seventeenth and eighteenth centuries, such as magnetism, motion, matter, and optics. He found that occult subjects enabled Jesuit priests and educators to combine their pastoral and scientific pursuits, "to seek a pedagogy capable of making the human soul sensitive in order to place it on the path of harmony and, consequently, revelation."26

\section{$1 \quad$ Christoph Clavius}

In order to place French Jesuit mathematical pedagogy in its historical context, Romano devoted two chapters to Clavius and his successful efforts to establish mathematics as part of the Jesuit curriculum. His success was the main reason why Jesuits were at the forefront of scientific activity in early modern Europe. Clavius, professor of mathematics at the Collegio Romano,

was a product of the explosive early growth of the Society of Jesus and founder of its traditions in the mathematical sciences; a venerable and authoritative educator, who taught and wrote among the Roman Jesuits for nearly half a century; an internationally known astronomer and mathematician whose textbooks became standards; the expert to whom ecclesiastical authorities looked as they formed their earliest opinions on Galileo's challenges to the established natural philosophy; and finally, the defender, and almost the very embodiment, of the traditional amalgam of Aristotelian cosmology and Ptolemaic astronomy. ${ }^{27}$

Clavius produced numerous modern editions of Euclid's Elements. Seventeenthcentury Jesuits viewed Clavius as their modern Euclid, "not only because of his edition of the Elements," as Lattis wrote, "but also because of the tutelage they had received from his many other textbooks on geometry, arithmetic, and, in

1999; and Bernard Barthet, Science, histoire et thématiques ésotériques chez les Jésuites en France (1680-1764) Bordeaux: Presses Universitaires de Bordeaux, 2012.

26 Barthet, 50: "rechercher une pédagogie capable de sensibiliser l'âme humaine pour la placer sur le chemin de l'harmonie et, partant, de la révélation."

27 James M. Lattis, Between Copernicus and Galileo: Christoph Clavius and the Collapse of Ptolemaic Cosmology (Chicago: University of Chicago Press, 1994), 29. 
particular, astronomy."28 Clavius also wrote several editions of commentaries on the important thirteenth-century textbook of astronomy, the Sphere of Sacrobosco. Lattis concentrated on Clavius as an astronomer rather than as a mathematician. He looked at the various editions of the commentaries on The Sphere, and how successive editions dealt with new material in sixteenth-century astronomy, particularly Copernicus's On the Revolutions and its superior handling of the precession of the equinoxes; the supernova of 1572, which dealt a blow to the Aristotelian idea of the incorruptibility of the heavens; and the comet of 1577 and Tycho Brahe's observations that showed its orbit was supralunar as well as sublunar, which dealt a blow to Aristotle's separation of the supralunar and sublunar spheres. In Lattis's telling, Clavius was an up-to-date scholar who grappled with the most important cosmological questions of his day. ${ }^{29}$

It is important to realize that there were very few Copernicans in Clavius's generation; Clavius was aware of the work of both Copernicus and Tycho Brahe, but their incompatibility with accepted physics and the lack of observational confirmation of the Copernican system, as well as the presumed geocentricity of the Bible, convinced him, like many others, that Ptolemy's system was most probable. Nevertheless, Clavius used the precession calculations from Copernicus's On the Revolutions to help him with what is perhaps his most famous accomplishment- the reform of the calendar. And for those who think that Protestantism was per se more amenable to the reform of astronomical sciences than Catholicism, it is worth noting that the reform of the calendar, also a major accomplishment in astronomy, was not adopted in England because it was considered Catholic until the mid-eighteenth century, about the same time that Jesuits began to teach the Copernican system as astronomical fact rather than hypothesis.

While Clavius's central role in Jesuit science and mathematics is widely acknowledged, the literature on him does not reflect this position. The book by Lattis is the only monograph of which I am aware, and it focused on Clavius's astronomical thought, with relatively little attention paid to his mathematics and teaching. Romano's chapters on Clavius did fill some of these lacunae. Four papers, by Saverio Corradino, Eberhard Knobloch, Giulio A. Lucchetta, and Antonio C. Garibaldi, from the proceedings of a 1993 conference on Clavius in Chieti dealt with his mathematics, while the other papers looked at other Jesuits and contemporaries. ${ }^{30}$ Ugo Baldini's chapter on

28 Ibid., 3 .

29 Ibid., chap. 6, "Strains on Ptolemaic Cosmology, Inside and Out."

$30 \quad$ Ugo Baldini, ed., Christoph Clavius e l'attività scientifica dei Gesuiti nell'età di Galileo. (Rome: Bulzoni Editore, 1995). 
Clavius includes appendices listing Clavius's course materials and students and a complete list of his works. ${ }^{31}$ Baldini also pointed out that work needs to be done on Clavius's Algebra and on unpublished material available to Clavius and his collaborators, ${ }^{32}$ but scholars have yet to follow up on these suggestions.

2

\section{The Galileo Affair}

Toward the end of Clavius's life, Galileo published The Starry Messenger, which announced his discoveries with the telescope, and Clavius and his students were among the first to look through Galileo's instrument. While there were hints of Copernican sympathies among those students (though not the professor), the Catholic church's condemnation of Copernican cosmology in 1616 meant that Jesuits, like other good Catholics, would not accept that cosmology for well over a century. ${ }^{33}$ Those students of Clavius realized that the Ptolemaic system was incompatible with Galileo's findings; however, sunspots, the phases of Venus, the irregularity of the moon's surface, and the moons of Jupiter were all compatible with the system invented by Tycho Brahe, the geoheliocentric system whereby five planets revolve around the sun as the sun and the moon revolve around the earth. Thus, Jesuit astronomers in the seventeenth century adopted the Tychonic system.

The Galileo Affair has traditionally been used as the proof that the Catholic church and the Jesuits were anti-science but, as so often with such dramatic events, the history was far more complex, as was the Jesuit role in the affair. William A. Wallace, for example, has shown in several works that "in his long career Galileo had contacts with a number of Jesuits; moreover, some of these contacts, particularly those before 1612, proved remarkably fruitful for the development of the 'new sciences' in which Galileo was interested. The connections that developed were intellectual, not personal, and their overall influence on Galileo's science was positive, not negative." ${ }^{34}$ Wallace found notes in

31 Ugo Baldini, "The Academy of Mathematics of the Collegio Romano from 1553 to 1612," in Feingold, 47-98.

32 Ibid., 63 .

33 Lattis, 204.

34 William A. Wallace, "Galileo's Jesuit Connections and Their Influence on His Science," in Feingold, 99. See also idem, Galileo and His Sources: The Heritage of the Collegio Romano in Galileo's Science (Princeton: Princeton University Press, 1984) and William A. Wallace, trans. Galileo's Early Notebooks (Notre Dame: University of Notre Dame Press, 1977). There appears similar complexity in Descartes's relations with the Jesuits in Roger Ariew, "Descartes and the Jesuits: Doubt, Novelty, and the Eucharist," in Feingold, 157-194. 
Galileo's handwriting that showed Jesuit influence, both positive and negative: he learned from them how to construct a scientific argument, and his debates with them forced him to streamline his thought. One of his Jesuit colleagues, Giuseppe Biancani (1566-1624), who is usually remembered for his arguments against the Copernican system, went so far as to adopt Galileo's position on floating bodies in one of his treatises, but it was censored at the time. ${ }^{35}$ Biancani, like Clavius and other Jesuits, such as Orazio Grassi (1583-1654), were connected to Galileo through a Roman scientific society, the Accademia dei Lincei. ${ }^{36}$

The first trial of Galileo in 1616, in which the Jesuit theologian Robert Bellarmine played a major role, resulted in the condemnation of the Copernican thesis and forbade Galileo from supporting it. The second in 1633 resulted in Galileo being forced to recant his belief in the Copernican thesis. These are certainly the most notable events in the encounter between Galileo and the Jesuits. Traditional historiography has seen this as one of the most dramatic proofs of the clash between science and the Catholic church. Recent historiography has softened that interpretation. ${ }^{37} \mathrm{~A}$ significant new interpretation of the relationship between Galileo and the Jesuits was advanced by Pietro Redondi, who suggested that Galileo really was guilty of heresy because his book The Assayer (1623) promoted atomism, and the lesser charge of Copernicanism saved his life. ${ }^{38}$ The Assayer specifically targeted Grassi. Redondi found an anonymous document that made the accusation of atomist heresy against Galileo and claimed that it was written by the grudge-bearing Grassi. ${ }^{39}$ In fact, the document was not written by Grassi. ${ }^{40}$ The fact that Redondi still emphasized the affair as a conflict between science and the

35 Wallace, "Galileo's Jesuit Connections," 108-og. See also Richard J. Blackwell, Galileo, Bellarmine, and the Bible (Notre Dame: University of Notre Dame Press, 1991), 148-153.

36 On Jesuit relations with Galileo through the academy, see David Freedberg, The Eye of the Lynx: Galileo, His Friends, and the Beginnings of Modern Natural History (Chicago: University of Chicago Press, 2002).

37 See, for example, J.L. Heilbron, Galileo (Oxford: Oxford University Press, 2010); Richard J. Blackwell, Behind the Scenes at Galileo's Trial (Notre Dame: University of Notre Dame Press, 2006), esp. chap. 4 on relations with Christoph Scheiner. William R. Shea and Mariano Arigas, Galileo in Rome: The Rise and Fall of a Troublesome Genius (Oxford: Oxford University Press, 2003), went to extreme lengths in blaming Galileo for the whole affair.

38 Pietro Redondi, Galileo Heretic, trans. Raymond Rosenthal (Princeton: Princeton University Press, 1987; orig. pub. Galileo eretico, 1983).

39 Ibid., 179-202.

40 William A. Wallace, rev. of Galileo eretico by Pietro Redondi, Isis 76 (1985): 379-380. 
church led Rivka Feldhay to explore what she viewed as a different conflict between the Dominicans and the Jesuits. ${ }^{41}$ The condemnation of the Copernican thesis in 1616 allowed for its study as a hypothesis, and Feldhay claimed that the Jesuits took full advantage of this while the Dominicans still avoided studying it, thus exposing the Jesuits to suspicions of heresy. ${ }^{42}$ While Feldhay showed the flexibility of the Jesuit approach, which encouraged their engagement with the sciences, it has been pointed out that she assumed a monolithic Society of Jesus that simply did not exist. ${ }^{43}$ Irving A. Kelter has interestingly shown that Jesuit theologians pursued a literal reading of the Bible regarding the Copernican thesis. ${ }^{44}$

\section{$3 \quad$ Athanasius Kircher}

A seventeenth-century successor to Clavius, Athanasius Kircher (1602-1680), was so colorful that he was the subject of a recent popular biography. ${ }^{45}$ Two exhibitions have been devoted to Kircher and his work, one in Rome and one in Stanford. ${ }^{46}$ A prolific writer, Kircher wrote on many subjects of interest to his contemporaries; he was at the center of a network of Jesuit correspondents and a filter for information; his museum at the Collegio Romano was not only a collection of antiquities and curiosities from around the world but also a laboratory for experiment and the study of the natural world. He grappled with such natural phenomena as magnetism, electricity, volcanoes, fossils, cosmology, and disease.

Paula Findlen pioneered the consideration of museums as part of the history of science, and Kircher was one of the heroes of her book, Possessing

41 Rivka Feldhay, Galileo and the Church:Political Inquisition or CriticalDialogue?(Cambridge: Cambridge University Press, 1995), 9.

42 Ibid., 188.

43 See, for example, Ernan McMullin, rev. of Galileo and the Church: Political Inquisition or Critical Dialogue? by Rivka Feldhay, American Historical Review 103 (1998): 873-875.

44 Irving A. Kelter, "The Refusal to Accommodate: Jesuit Exegetes and the Copernican System," rev. version in The Church and Galileo, ed. Ernan McMullin, 38-53 (Notre Dame: University of Notre Dame Press, 2005; orig. pub. 1995).

45 John Glassie, A Man of Misconceptions: The Life of an Eccentric in an Age of Change (New York: Riverhead, 2012). Unfortunately, the author misconceives the times and, therefore, the man.

46 Ingrid Rowland, The Ecstatic Journey: Athanasius Kircher in Baroque Rome (Chicago: University of Chicago Press, 200o); Daniel Stolzenberg, ed., The Great Art of Knowing: The Baroque Encyclopedia of Athanasius Kircher (Stanford: Stanford University Libraries, 2001). 
Nature. ${ }^{47}$ She then edited a volume about Kircher, Athanasius Kircher: The Last Man Who Knew Everything, which dealt with much of his life and work: his life (Eugenio Sardo, Martha Baldwin, Harald Siebert, Angela Mayer-Deutsch); aspects of his work (Egyptian writings by Peter N. Miller, Kabbalah by Daniel Stolzenberg, chronology by Anthony Grafton, cosmology by Ingrid Rowland, paleontology by Stephen J. Gould, magnetism by Michael John Gorman); dissemination of his work (Haun Saussy, Nick Wilding, Noel Malcolm); relations beyond Europe (Carlos Ziller Camenietzki, Findlen, J. Michelle Molina, Florence Hsia); and the historical context of his prodigious productivity (Antonella Romano). ${ }^{48}$ It is a good introduction to Kircher.

There has been some writing about specific aspects of Kircher's work, although a lot remains to be more thoroughly explored. Harald Siebert studied the cosmological issues in Kircher's Ecstatic Journey; Siebert suggested that it should be seen as an early work of science fiction along the lines of Johannes Kepler's Somnium. Though Kircher explored the implications of the Tychonic system rather than the Copernican system, Siebert importantly reminded his readers that at the time it was written in 1656 "[b]oth systems, the Tychonic like the Copernican, explain[ed] the celestial phenomena without contradiction and [were] mathematically equivalent," 49 and using the Tychonic system allowed Kircher "to argue for the possibility of the physical phenomenon of magnetism of the Copernicans" while he denied "the argument for the motion of the earth."50 In its time, the Ecstatic Journey was a significant book of cosmology. Likewise Daniel Stolzenberg has shown that Kircher's use of the occult as he tried to unlock the secrets of ancient wisdom was not outlandish in his time. ${ }^{51}$ To Stolzenberg the book represented "a complex moment when

47 Paula Findlen, Possessing Nature: Museums, Collecting, and Scientific Culture in Early Modern Italy (Berkeley: University of California Press, 1994). See also idem, "Anatomy Theaters, Botanical Gardens, and Natural History Collections," in Park and Daston, 290-305.

48 Paula Findlen, ed., Athanasius Kircher: The Last Man Who Knew Everything (New York: Routledge, 2004).

49 Harald Siebert, Die grosse kosmologische Kontroverse: Rekonstruktionsversuche anhand des Itinerarium exstaticum von Athanasius Kircher SJ (1602-1680) (Stuttgart: Franz Steiner Verlag, 2006). "Beide Systeme, das tychonische wie das copernicanische erklären widerspruchsfrei die Himmelsphänomene und sind such mathematisch gleichwertig" (16).

50 Ibid., 18. "Es gelang ihm, den Copernicanern das physikalische Phänomen des Magnetismus also mögliches Argument für die Erdbewegung abzunehmen."

51 Daniel Stolzenberg, Egyptian Oedipus: Athanasius Kircher and the Secrets of Antiquity (Chicago: University of Chicago Press, 2013). 
empiricism and esotericism coexisted" and gave rise to the discipline of oriental studies from "an early modern Mediterranean world in which texts, artifacts, and scholars circulated between Christian and Islamic civilizations." ${ }^{52}$ Kircher failed in his attempt to read and understand hieroglyphics, as he failed in many of his endeavors. But his work was important for his contemporaries: they discussed it, and they tried to duplicate his experiments, and so he affected the work of those whom we remember today as figures who advanced science. As Findlen pointed out, "Scholars read and responded to his encyclopedias because they represented an intriguing stage in the evolution of many different scholarly disciplines, often all in the same thick volume."53 Though he may not have always been forward-looking, he influenced the work of those who were; so he was necessary to the advance of science.

\section{4}

Other Jesuit Scholars

Some work has been done on other important Jesuit thinkers. A short volume on Scheiner by Franz Dexecker provided details about his life, correspondence, and work, particularly on optics, that added important details about his contributions. ${ }^{54}$ Giambattista Riccioli not only contributed to our understanding of the heavens, but, as Alfredo Dinis showed, he added to our knowledge of arithmetic, geometry, optics, gnomonics, geography, and chronology. 55 Domenico Bertoloni Meli discussed how Riccioli's experiments on pendular motion and falling bodies added to our knowledge of mechanics. ${ }^{56}$ Papers from a conference in Ferrara and Bondeno celebrating the quadricentennial of Riccioli's birth examined his work in astronomy and mechanics (Dinis, Juan Casanovas, Ugo Baldini, Fabrizio Bònoli), as well as his theological writings. ${ }^{57}$ Heilbron introduced the work by Niccolò Cabeo (1586-1650) on magnetism. ${ }^{58}$ Much work remains to be done on these figures and the many other Jesuits who were writing about the natural world in the seventeenth century.

$52 \quad$ Ibid., 6 .

53 Findlen, Introduction to Athanasius Kircher, 8.

54 Franz Daxecker. The Physicist and Astronomer Christopher Scheiner: Biography, Letters, Works (Innsbruck: Leopold-Franzens-University of Innsbruck, Public-Relations Office, 2004).

55 Alfredo Dinis, "Giovanni Battista Riccioli and the Science of His Time," in Feingold, ed., 195-224.

56 Domenico Bertoloni Meli, Thinking with Objects: The Transformation of Mechanics in the Seventeenth Century (Baltimore: Johns Hopkins University Press, 2006), 131-134.

57 Maria Teresa Borgato, ed., Giambattista Riccioli e il merito scientifico dei gesuiti nell'età barocca (Florence: Leo S. Olschki, 2002).

$5^{8}$ Heilbron, Electricity, 180-183. 


\section{Jesuit Missions in Asia and the Americas}

Within a decade of the Society's creation, Jesuit missionaries went to spread the word in Asia and the Americas. They brought with them their education, and they corresponded with their confrères in Europe. They brought scientific instruments, including telescopes, and on their voyages they made measurements of both the earth and the sky, importantly correcting maps of both as they traveled.

\section{$1 \quad$ China}

The Jesuit mission in China was so important to Chinese mathematics and astronomy that Joseph Needham, in his pathbreaking work Science and Civilization in China, devoted a section to the Jesuit contributions of the seventeenth century. ${ }^{59}$ While Needham broke with the traditional view of advanced science as principally a European phenomenon, he was still influenced by the Copernican bias of that tradition. Thus, he gave the Jesuits credit for bringing superior methods of predicting eclipses, Euclidean geometry, the use of geometry in charting the movements of celestial bodies and in surveying, new methods of computing, and new instruments including the telescope. On the other hand, he accused the Jesuits of virtually forcing Ptolemaic astronomy on the Chinese and retarding their acceptance of Copernican astronomy. ${ }^{60}$ However, in the seventeenth century, most Jesuits taught Tychonic, not Ptolemaic, astronomy. A recent work on Chinese science noted that when the eighteenth-century Jesuit, Michel Benoit (1715-1774) presented Copernican astronomy to the Chinese, "Chinese literati thought the presentations too incoherent to take seriously."61 The Chinese could reject Copernicus without Jesuits compelling them.

Florence Hsia's Sojourners in a Strange Land told the story of the China mission and its success both in opening China to the Jesuits and presenting that story to Europeans. At the center of this story was mathematics: "had Chinese auditors been more interested in the niceties of French or Italian cuisine than in Aristotelian cosmology or Tychonic instrumentation, the present book might well be a history of Jesuit chefs in the Celestial Empire."62 Hsia set her

\footnotetext{
59 Joseph Needham, Science and Civilization in China, vol. 3, Mathematics and the Sciences of the Heavens and the Earth (Cambridge: Cambridge University Press, 1959), 437-461.

6 o Ibid., 437-438.

61 Benjamin A. Elman, On Their Own Terms: Science in China, 1550-19oo (Cambridge: Harvard University Press, 2005), xxvi.

62 Florence C. Hsia, Sojourners in a Strange Land:Jesuits and Their Scientific Missions in Late Imperial China (Chicago and London: University of Chicago Press, 2009), 5.
} 
story within the context of Matteo Ricci's description of his experiences in China, De Christiana expeditione apud Sinas suscepta ab Societate Jesu (1615) and Guy Tachard's Voyage de Siam des Pères Jésuites (1688) and showed how the Jesuits used mathematics to make inroads into Chinese society and just as the effort was presented as "a model for imitation," ${ }^{63}$ so other missionaries conformed to that model. Although China was the most successful of the Jesuit Asian missions, work like Hsia's on the other missions would contribute to our understanding of global scientific activities.

\section{$2 \quad$ Matteo Ricci}

Matteo Ricci (1552-1610) was crucial to the success of the China mission. He had studied mathematics and astronomy at the Collegio Romano with Clavius and was a gifted mathematician. He realized that his mission in China depended on the ruling class, and so he studied Chinese and Confucian writings, he dressed and behaved like a mandarin, and he used mathematics and science to interest the Chinese. He brought valuable instruments, including a chiming clock that entranced them. Using European astronomy, he was able to predict eclipses, important for the imperial calendar, better than the imperial astronomers. He taught Euclidean geometry to the Chinese elite and translated Euclid's Elements into Chinese.

As colorful a figure as Matteo Ricci is bound to excite non-scholars, and, indeed, a popular biography recently appeared. ${ }^{64}$ Ronnie Po-chia Hsia's biography gave a fuller discussion of all aspects of Ricci's career, as teacher, author, scholar, diplomat, priest, and missionary. "With his expertise in mathematics and astronomy, his library of western books and western scientific instruments, Ricci, the Master of the Way, was worthy of the attention of Confucian literati," 65 and it was through these contacts that Ricci established a Jesuit mission in China that still operates there.

\section{$3 \quad$ The Americas}

Less attention has been paid to the scientific achievements in the Americas than in Asia, which makes Andrés I. Prieto's book on the Spanish missions in

\footnotetext{
63 Ibid., 29 .

64 Michela Fontana, Matteo Ricci: Un gesuita alla corte dei Ming (Milan: Arnoldo Mondadori Editore, 2005); English trans. by Paul Metcalfe, Matteo Ricci: A Jesuit in the Ming Court (Lanham: Rowman \& Littlefield, 2011). While good overall, its science relies completely on Needham and is, consequently, not a good discussion of Ricci's scientific contributions.

65 R. Po-chia Hsia, A Jesuit in the Forbidden City: Matteo Ricci 1552-1610 (Oxford: Oxford University Press, 2010), 136.
} 
South America welcome. ${ }^{66}$ The South American mission differed considerably from the mission in China, and interest in the natural world often focused more on the earth than the sky. "Both the practical and theological challenges presented by autochthonous cultures and the need to survive in what was often an aggressive and unfamiliar environment forced the missionaries to describe, explain, and utilize nature and the indigenous lore about it." ${ }^{27}$ Prieto noted that Jesuits in South America often left the cities to live among the inhabitants and needed to learn the local language, customs, and nature to succeed. They also had to compete with the shamans: "Since shamans drew their authority and prestige mainly from their ability as healers, the missionaries were forced to assume the role of medicine men in the missions if they were to displace them as spiritual leaders. Under these circumstances, the knowledge of the medicinal uses of local flora was of paramount importance for the missionaries." ${ }^{68}$ And like their confreres elsewhere, the missionaries in South America had to try to explain nature in the context of the Aristotelian foundations of their instruction. Aristotle had claimed that life was impossible in the torrid zone. How did a missionary in Peru, not far from the equator, deal with that: or not deal with it, as in the case of José de Acosta $(1540-1600) ?^{69}$

\section{Conclusion}

While a lot of research has been conducted on the vast amount of work and the significant contributions of Jesuits to early modern science, much remains to be done. Scholars must continue to study the work of the individual Jesuits I have mentioned who were active in exploring the natural world-Riccioli, Grimaldi, Biancani, Scheiner, Schott, Grassi, Cabeo, and Tachard. Even the work of Clavius, Kircher, and Ricci has not been exhausted. The tight network of the Society left a trove of letters as well as unpublished manuscripts and published books that give the scholar important sources to examine. More work needs to be done on the missions, not only in Latin America and China, but also in India and Japan. But already it is clear that, contrary to the

\footnotetext{
66 Andrés I. Prieto, Missionary Scientists: Jesuit Science in Spanish South America, 1570-1810 (Nashville: Vanderbilt University Press, 2011).

67 Ibid., 4 .

68 Ibid., 41.

69 Ibid., 152.
} 
traditional historiography of early modern science, we cannot grasp the subject without including the many positive contributions of Jesuits, and recent overviews reflect this. ${ }^{70}$

70 See, for example, Peter Dear, Revolutionizing the Sciences, 2d ed. (Princeton: Princeton University Press, 2009; orig. pub. 2001) and Ofer Gal and Raz Chen-Morris, Baroque Science (Chicago: University of Chicago Press, 2013). 